\title{
Suomalais-Ugrilaisen Seuran säännöt
}

Hyväksytty Seuran vuosikokouksessa joulukuun 2. päivänä 2007

1. § Yhdistyksen nimi on Suomalais-Ugrilainen Seura, ja sen kotipaikka on Helsinki. Seuran nimestä käytetään eri kielillä seuraavia epävirallisia asuja: pohjoissaameksi Suoma-Ugralaš Searvi, viroksi Soome-Ugri Selts, unkariksi Finn-Ugor Társaság, ruotsiksi Finsk-Ugriska Sällskapet, ranskaksi Société Finno-Ougrienne, saksaksi Finnisch-Ugrische Gesellschaft, englanniksi Finno-Ugrian Society, venäjäksi Финно-Угорское Общество ja latinaksi Societas Fenno-Ugrica.

2. § Seuran tarkoituksena on edistää uralilaisten ja altailaisten kansojen kielten, kulttuurien ja historian tutkimusta.

\section{3. $\S$ Tarkoituksensa toteuttamiseksi Seura}

3.1 lähettää tutkijoita harjoittamaan kenttä- ja arkistotutkimusta mainittujen kansojen keskuuteen sekä muualle, missä tällaisen tutkimuksen kannalta tarpeellista aineistoa on saatavilla;

3.2 tukee henkilöitä ja työryhmiä, jotka omasta aloitteestaan harjoittavat Seuran työaloihin liittyvää tieteellistä tutkimusta ja keruuta;

3.3 tukee apurahoin mainittuja työaloja edustavien tieteellisten tutkimusten ja aineskokoelmien valmistamista julkaistaviksi;

3.4 kustantaa ja julkaisee työaloihinsa suoranaisesti tai välillisesti kuuluvaa tieteellistä kirjallisuutta sekä huolehtii tämän kirjallisuuden varastoinnista ja markkinoinnista;

3.5 osallistuu julkaisuillaan tieteellisen kirjallisuuden vaihtoon sekä huolehtii näin saadun vaihtokirjallisuuden käyttöön asettamisesta;

3.6 ylläpitää arkistoa ja tarpeen mukaan muita kokoelmia sekä huolehtii näiden sijoittamisesta tutkijoiden käyttöön;

3.7 pitää kokouksia sekä järjestää esitelmä- ja keskustelutilaisuuksia ajankohtaisten tieteellisten kysymysten pohtimista ja tunnetuksi tekemistä varten.

4. § Seuran jäseneksi voidaan valita tai kutsua hyvämaineinen henkilö kansallisuudesta tai kansalaisuudesta riippumatta. Lahjoittajajäseneksi voidaan hyväksyä myös oikeuskelpoinen yhteisö. Jäsenet ovat 
4.1 kunniajäseniä, joiksi kutsutaan Seuran työalojen kansainvälistä huippua edustavia tai Seuran pyrkimyksiä muuten suuresti edistäneitä henkilöitä;

4.2 ulkojäseniä, joiksi kutsutaan Suomen ulkopuolelta Seuran työaloihin liittyvää tutkimusta menestyksellisesti harjoittavia henkilöitä;

4.3 lahjoittajajäseniä, joiksi hyväksytään Seuran toimintaa lahjoituksin tukeneita henkilöitä ja oikeuskelpoisia yhteisöjä;

4.4 vakinaisia jäseniä, jotka jäsenmaksuna suorittavat vuosikokouksen kulloinkin vahvistaman summan.

Ne, jotka ennen näiden sääntöjen voimaan astumista ovat suorittaneet jäsenmaksunsa tai tulleet Seuran jäseniksi aikaisempien perusteiden mukaan, jäävät edelleenkin Seuran jäseniksi niillä nimityksin kuin aikaisemmissa säännöissä on vahvistettu.

5. $\S$ Kunnia- ja ulkojäsenet valitsee vuosikokous marraskuun varsinaisessa kokouksessa tehtyjen kirjallisten esitysten perusteella. Kunnia- ja ulkojäseniltä ei peritä mitään maksuja. Lahjoittajajäsenet hyväksytään varsinaisessa kokouksessa johtokunnan esityksestä, vakinaiset jäsenet taas kenen tahansa läsnä olevan jäsenen ehdotuksesta sillä edellytyksellä, että jäseneksi ehdotettu on suorittanut jäsenmaksun. Mikäli ehdotusta vakinaiseksi jäseneksi ei hyväksytä, jäsenmaksu palautetaan. Ehdotus jäsenen erottamiseksi Seurasta on aina siirrettävä käsiteltäväksi seuraavaan kokoukseen, jossa ehdotus voidaan hyväksyä vain siinä tapauksessa, että sitä kannattaa vähintään kaksi kolmannesta läsnä olevista jäsenistä. Muussa tapauksessa ehdotus katsotaan rauenneeksi eikä siitä tehdä merkintää pöytäkirjaan.

\section{6. $\S$ Seuran rahastot ovat}

6.1 pohjarahasto, johon menevät lyhentämättöminä kaikki jäsenmaksut ja jonka pääoma on säilytettävä vähentämättömänä;

6.2 yleinen rahasto, johon siirretään tilivuoden ylijäämä ja josta ensisijaisesti katetaan mahdolliset tappiot;

6.3 erityisrahastot, jotka ovat syntyneet tai vastedes syntyvät varta vasten lahjoitetuista tai erityisiin tarkoituksiin määrätyistä varoista ja joiden hoitoa, kartuttamista ja käyttämistä säätelevät kullekin rahastolle vahvistetut erityismääräykset.

7. $§$ Seuran tilit päätetään kalenterivuosittain. Maaliskuun varsinaisessa kokouksessa esitetään tilit ja tilintarkastajain niistä ja hallinnosta antama kertomus, vahvistetaan tilinpäätös sekä päätetään vastuuvapauden myöntämisestä tilivelvollisille. Tilinpäätös julkaistaan Suomalais-Ugrilaisen Seuran Aikakauskirjassa. 
8. $\S$ Seuran toimimiehet ovat esimies, ensimmäinen ja toinen varaesimies, sihteeri, rahanvartija, kirjavarainhoitaja ja yliasiamies.

Esimies valvoo Seuran toimintaa, edustaa Seuraa korkeimmalla taholla, kutsuu kokoon johtokunnan kokoukset ja johtaa puhetta niissä sekä muissa kokouksissa lukuun ottamatta niitä asioita, joissa hän on lain mukaan esteellinen.

Ensimmäinen varaesimies ja hänen estyessään toinen varaesimies astuvat tarvittaessa esimiehen tilalle.

Sihteeri hoitaa Seuran kirjeenvaihdon, laatii vuosikertomuksen, valmistelee kokoukset, pitää pöytäkirjaa johtokunnan kokouksista, valvoo julkaisutoimintaa sekä ohjaa tarpeen mukaan Seuran muuta toimintaa.

Rahanvartija hoitaa Seuran taloutta: pitää varoista kirjaa, huolehtii Seuralle tulevista avustuksista ja lahjoituksista, saatavista ja jäsenmaksuista sekä sijoittaa Seuran varat.

Kirjavarainhoitaja valvoo Seuran julkaisujen varastointia, myyntiä ja vaihtoa sekä muiden kirjavarojen käyttöön asettamista.

Yliasiamies hankkii Seuralle uusia vakinaisia jäseniä sekä pyrkii edistämään Seuran kannatusta suuren yleisön keskuudessa, pitää pöytäkirjaa Seuran kokouksista ja avustaa tarpeen mukaan sihteeriä sekä valvoo Seuran ulkopuolisiin instituutioihin sijoitettua arkistoaineistoa.

Johtokunta voi ottaa tai palkata Seuralle yllä mainittujen lisäksi myös muita toimimiehiä ja työntekijöitä tilapäisten tai jatkuvaluonteisten tehtävien suorittamiseen. Etujansa valvomaan Seura voi asettaa erityisiä asiamiehiä eri paikkakunnille sekä Suomeen että muihin maihin.

9. $\S$ Seuran toimintaa koskevat asiat käsittelee ja niistä päätökset tekee hallituksena toimiva johtokunta, johon kuuluvat esimies, molemmat varaesimiehet, sihteeri, rahanvartija, kirjavarainhoitaja sekä kolme lisäjäsentä. Johtokunta on päätösvaltainen, jos läsnä on yksi esimiehistä sekä neljä muuta jäsentä.

10. $\S$ Seuran nimenkirjoittajat ovat esimies ja varaesimiehet, kaksi yhdessä tai joku heistä yhdessä sihteerin tai rahanvartijan kanssa.

11. $§$ Seuran kokoukset ovat varsinaisia kokouksia, ylimääräisiä kokouksia ja vuosikokouksia. Kokouksissa pitää pöytäkirjaa Seuran yliasiamies tai hänen estyessään sihteeri. Asiat ratkaistaan avoimella äänestyksellä, ellei vähintään kaksi jäsentä vaadi umpilippuäänestystä, sekä yksinkertaisella äänten enemmistöllä tai äänten sattuessa tasan arvalla. Jäsenen erottamiseen, sääntöjen muuttamiseen tai Seuran purkamiseen vaaditaan kuitenkin sellainen enemmistö kuin näissä säännöissä on erikseen ilmoitettu. 
12. § Varsinaiset kokoukset Seura pitää syyskuun ja marraskuun sekä tammikuun ja toukokuun välisinä aikoina kunkin kuukauden kolmantena perjantaina, elleivät erityiset syyt vaadi kokouksen siirtämistä joksikin muuksi ajankohdaksi. Kokouspäivämäärät vahvistaa johtokunta, joka myös päättää ylimääräisistä kokouksista. Kokouksissa pidetään esitelmiä, esitetään ehdotukset uusiksi vakinaisiksi ja lahjoittajajäseniksi sekä ratkaistaan jäsenen erottamista koskevat ehdotukset. Maaliskuun ja marraskuun kokouksissa käsitellään lisäksi ne asiat, jotka näissä säännöissä on erikseen ilmoitettu.

13. § Vuosikokous pidetään Matias Aleksanteri Castrénin syntymäpäivänä 2. joulukuuta tai esteen sattuessa jonakin muuna joulukuun päivänä. Vuosikokouksen avaa esimies tai varaesimies puheella tai esitelmällä, minkä jälkeen luetaan sihteerin laatima vuosikertomus ja rahanvartijan laatima selonteko vuoden tuloista ja menoista. Vuosikokouksessa valitaan marraskuun varsinaisessa kokouksessa tehtyjen kirjallisten esitysten perusteella uudet kunnia- ja ulkojäsenet sekä Seuran toimimiehet ja johtokunnan lisäjäsenet seuraavaan vuosikokoukseen saakka ynnä kaksi tilintarkastajaa ja heidän varamiehensä tarkastamaan seuraavan kalenterivuoden tilit. Niin ikään vahvistetaan Seuran talousarvio seuraavaksi vuodeksi sekä jäsenmaksujen suuruus ja ratkaistaan sääntöjen muuttamista koskevat ehdotukset.

14. §Varsinaisista kokouksista ilmoitetaan viimeistään kolme päivää ennen kokousta Seuran verkkosivuilla. Ylimääräisistä kokouksista sekä vuosikokouksesta, jos se pidetään joulukuun 2. päivästä poikkeavana päivänä, on lisäksi ilmoitettava kahdesti, viikon väliajoin, toisen kerran viimeistään kokousta edeltävänä päivänä Helsingin Sanomissa.

15. § Ehdotus näiden sääntöjen muuttamiseksi on tehtävä Seuran varsinaisessa kokouksessa viimeistään marraskuussa, jotta ehdotus tulisi käsiteltäväksi ja ratkaistavaksi lähinnä seuraavassa vuosikokouksessa. Kummankin kokouksen kutsussa on tällöin erityisesti ilmoitettava, että ehdotus sääntöjen muuttamisesta tulee esille. Muutos katsotaan hyväksytyksi vain siinä tapauksessa, että vähintään kaksi kolmannesta läsnäolevista jäsenistä kannattaa sitä.

16. § Jos tehdään ehdotus Seuran purkamisesta, on päätös siitä tehtävä samoin kuin sääntöjen muutoksista on ilmoitettu. Jos Seura purkautuu, varat on jätettävä Seuran kokouksessa päätettävällä tavalla käytettäväksi Seuran tarkoituksen edistämiseen. Jos Seura purkautuu, on huolehdittava siitä, että erityisiä tarkoituksia varten määrätyt rahastot edelleenkin tulevat hoidettaviksi ja käytettäviksi sääteentekijän määräämällä tavalla.

Suomalais-Ugrilainen Seura, PL 320 (Mariankatu 7 A), 00171 Helsinki, puhelin (09) 662149 ja telekopio (09) 6988249. 